\title{
Et krigsmonument fra 1134?
}

\author{
af H.E. SøRENSEN
}

Forfatteren H.E. Sørensen har ladet sig fascinere af døbefonten i Felsted kirke og vover her en tolkning af den gamle stenhuggers fornemme arbejde. Er billederne en reportage fra slaget ved Fodevig 1134, og rummer fonten et politisk budskab? Det endelige svar får vi næppe nogensinde, men Felstedfonten fortjener ligesom mange andre opmærksomhed. Den kan sende tankerne på langfart.

Felsted kirke er opført i romansk stil omkring midten af det 13. århundrede. Nationalmuseet daterer den gavmildt til ca. 1225-75. Både mure og tagværk er oprindelige, og i nordmuren har en restaurering o. 1910 genåbnet de ellers tilmurede romanske vinduesåbninger. De sidder direkte under det flade bræddeloft, som har afløst en tøndehvælving af træ. Kirkeskibet er ganske højt og samtidig det bredeste i en landsbykirke i det gamle Aabenraa amt.

Kirken har bevaret et ganske rigt inventar fra middelalderen, herunder en stor og velskåret fløjaltertavle fra første halvdel af 15. århundrede, en mindre Mariatavle fra o. 1500, et korbuekrucifix fra samme tid flankeret af to helgenfigurer og en indskriftsløs gotisk messeklokke (ca. $30 \mathrm{~cm}$ høj). I det murede alterbord, der nok stammer fra kirkens opførelse, fandtes $i$ helgengraven en lille blyæske med en fint broderet byzantinsk pose fra 1200-tallet med små knoglestumper fra et menneskeligt kranium, nu på Nationalmuseet. Den kan være anbragt der $\mathrm{i}$ forbindelse med kirkens indvielse for 0.750 år siden. Hvilken helgen, relikvierne stammer fra, er ikke oplyst, men kirken var indviet til Sankt Dionysius. Det gør det ikke meget nemmere, da der fra oldkirkens tid findes flere hellige mænd af dette navn, herunder det medlem af de fornemme mænds råd (areopagos) i Athen, der omtales i Apostlenes Gerninger (17.34), kirkefaderen Dionysios af Alexandria (3. årh.) og den mest kendte af dem, den hellige Dionysius af Paris (Saint Denis), der ligeledes levede i det 3. århundrede. Han blev henrettet for sin tros skyld, men gik i følge legenden gennem byen med sit afhuggede hoved $\mathrm{i}$ hånden ud til landsbyen St. Denis, der fik navn efter ham, og hvor hans helgenkirke står. Væsentlige 


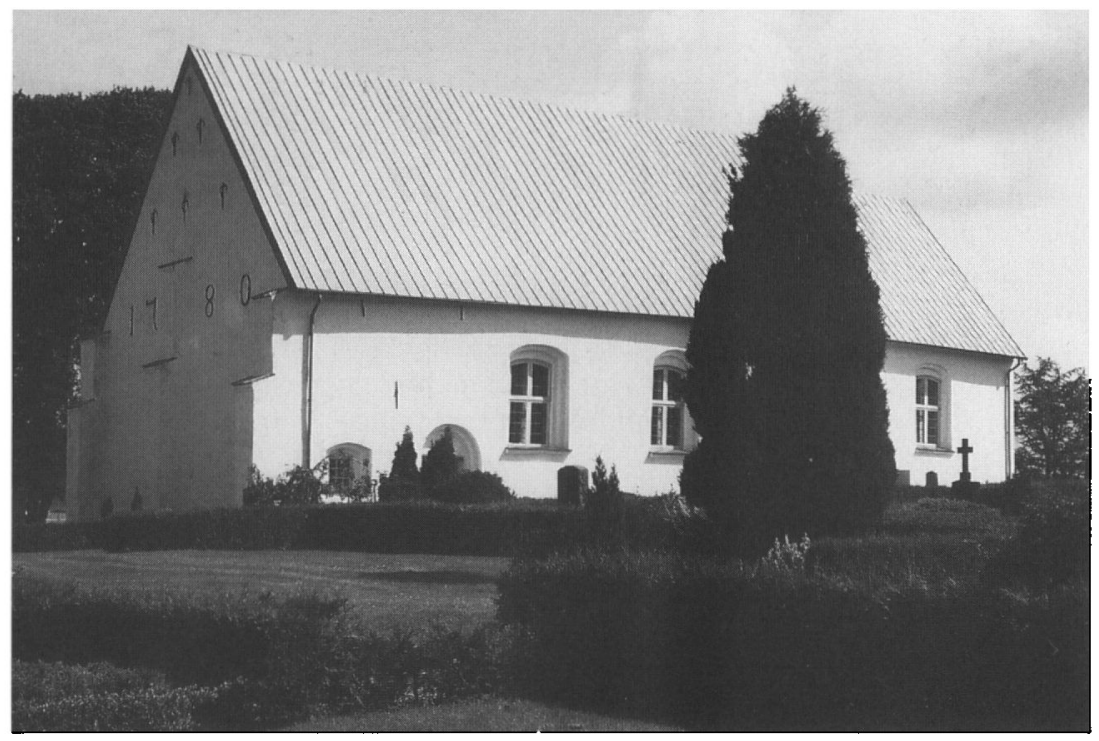

Felsted kirke set fra sydvest. Foto: H.E. Sørensen.

teologiske skrifter tillægges ham. Det er dog næppe sandsynligt, at man i Felsted har haft relikvier af denne betydelige franske teolog og kirkelærer - eller for så vidt af en af de to andre. Men det forhindrer naturligvis ikke, at man kan have troet det.

Det relativt sene opførelsestidspunkt viser, at kirken må have haft mindst én forgænger, sandsynligvis to - formentlig en stavkirke fra o. 1000 og en kampestenskirke fra 1100-tallet. Der kendes ingen spor af disse bygninger, men mindst en af dem må have eksisteret.

\section{Døbefonten}

Kirkens ældste inventarstykke er døbefonten, som vil blive nærmere behandlet $\mathrm{i}$ det følgende, hvor også en tydning af billederne såvel som en datering vil blive forsøgt. Den kan måske samtidig indikere, hvornår den formentlig anden kirke i Felsted er opfort.

Døbefonten er hjemligt arbejde, hugget i jysk granit, og består af en kumme ca. $80 \mathrm{~cm}$ i diameter og næsten lige så høj på en kvadratisk fod med sider på $0.70 \mathrm{~cm}$ og ca. $30 \mathrm{~cm}$ høj. De to dele hører tydeligvis sammen og må anses for en oprindelig helhed. Tilsammen har de form som en kalk. 


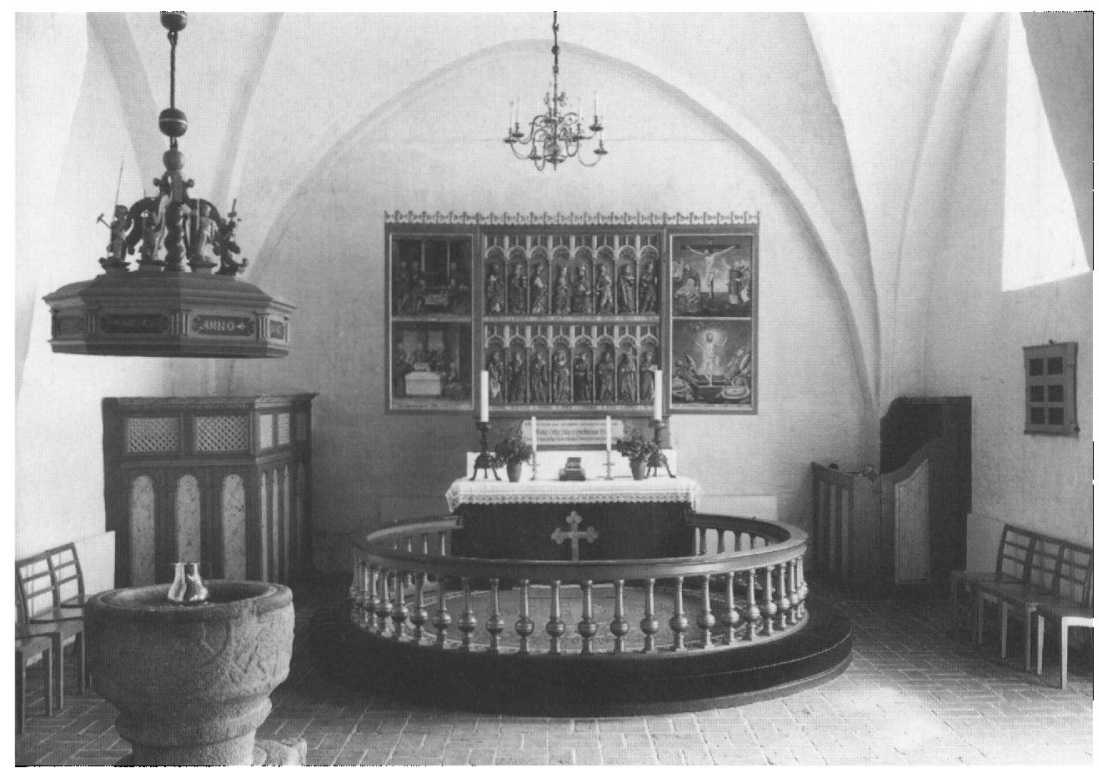

Felsted kirke. Korets indre med døbefonten, set mod øst. Foto: Nationalmuseet, København.

På fontefodens sider er udhugget dyrerelieffer, hvoraf to er (delvist) identificerbare. Mod vest ses en hund og mod syd (sandsynligvis) en hjort. Hvilke dyr, der kan have været på de to andre sider, kan i dag ikke ses. I fodens hjørner er udhugget fire barske mandshoveder, hvoraf to er ganske velbevarede, men de to andre er stærkt forvitrede. På issen af disse hoveder ses tydeligt en planhugget cirkel med en ca. $3 \mathrm{~cm}$ bred ring. Den runde flade kunne opfattes som base for en søjle, men det kan næppe være meningen, da det ikke er muligt at placere søjler her.

De kunne derimod have båret en hovedbeklædning, evt. en bispehuse, mitra, eller ringene kunne tydes som tonsur, d.v.s. den hårkrans, som munke og præster havde om den ellers glatragede isse. I begge tilfælde markeres, at der er tale om gejstlige personer, muligvis biskopper.

På randen af kummen findes en frise i lavt relief. Den viser set fra kirkeskibet mod højre følgende billeder: et skib med fire personer, en ridder med fane, en lilje, en hjort, der jages af to hunde over hinanden, en spydmand og endnu en ridder med fane. Reliefferne er ret primitivt hugget, men tydeligvis af en person med et godt øje for 
form og bevægelse. Trods det grove materiale er det væsentlige i dyrenes anatomi ramt præcist og levende. Man må derfor formode, at fonten er udført af en professionel stenhugger.

Der kan efter såvel udførelsen som stilen og motiverne ikke være nogen tvivl om, at fonten stammer fra 1100-tallet, sandsynligvis fra århundredets første halvdel.

Nationalmuseets direktør Mouritz Mackeprang, der var født på Kiding 1869 og således må formodes døbt i denne font, beskriver i "Danmarks middelalderlige døbefonte “ billedfrisen således: "En jæger med spyd og jagthorn jager med sine to hunde en hind; en stiliseret lilje, vel en slags signatur for skoven, hvori jagten foregår, skiller denne scene fra to opsadlede heste, hver med en fane, medens en båd med fire personer er anbragt mellem dem«. Han fortolker det som en illustration til »den med Hubertuslegenden nærtbeslægtede legende om den romerske høvedsmand Eustacius, der ligeledes omvendtes på en jagttur og derefter sammen med sin hustru og sine to sønner flygter til Ægypten“. - „Unægtelig er det lidt vanskeligt at passe hestene ind $\mathrm{i}$ denne fortolkning ", tilføjer han, "men $\mathrm{i}$ hvert fald dækker den fremstillingen adskillig bedre end den tidligere givne forklaring, hvorefter båden skulle hentyde til profeten Jonas«, således som den tyske kunsthistoriker dr. Ernst Sauermann havde foreslået $i$ »Die mittelalterlichen Taufsteine der Provinz Schlewig-Holstein«, 1904. Heri må man give Mackeprang ret, men det forekommer mig, at heller ikke hans fortolkning er tilfredsstillende, selv om den støttes af Søren Nancke-Krogh. En nærmere gennemgang af de enkelte billeder er derfor nødvendig.

\section{De enkelte billeder}

Skibet på relieffet er af tidlig middelalderlig type, et klinkbygget vikingeskib med høje stævne og sideror. Sideplankerne er tydeligt markeret med to streger, der følger skrogets form. Typen er den samme som den, der ses på skibsrelieffet i koret i Vilstrup kirke på Haderslev Næs, sandsynligvis fra samme tid, og på gotlandske billedsten fra sen vikingetid eller tidlig middelalder - d.v.s. 1000-1100. På stenene fra Hejnum Riddare og Eskelhem Larsave I på Gotland ses samme form og sideror som i Felsted og Vilstrup. Begge de gotlandske skibe har dragehoveder i stævnene, mens sådanne ikke findes på de to sønderjyske skibsbilleder. Især skibet fra Eskelhem Larsave I har stor lighed 
med Felstedskibet. Skibe af samme type, dog uden ror, ses på relieffer i Hansted kirke i Nordjylland og Bøstrup kirke på Langeland. Skibene på Bayeux-tapetet (La tapesserie de la reine Mathilde) i Bayeux i Nordfrankrig fra o. 1070 er af samme type, der også genfindes i det godt tretten meter lange vrag 3 fra Skuldelev (Vikingeskibshallen i Roskilde), der er dateret til 1030 plus/minus 100 år. Det kan således være fra tiden op imod eller kort efter 1100, men typen har sandsynligvis været ret uændret $\mathrm{i}$ flere hundrede år. Også den lille handelsskude (ca. otte meter lang), som for få år siden fandtes ved udgravningen til Museumsøen i Roskilde, og som nu er rekonstrueret i fuld størrelse (1999 udstillet på Nationalmuseet), er af samme type, ligesom Falsterbobåden, der er C14-dateret til o. 1100. Skibet på Felstedfonten kan således meget vel dateres til begyndelsen af 1100-tallet.

De ovrige billeder $i$ frisen viser helt klart, at vi befinder os i den periode, hvor riddervæsenet trængte ind over Danmarks grænser fra syd. De to riddere på Felsted-fonten rider i fuldt firspring med en fane på en lang stang $i$ hånden. Stangen er sandsynligvis en lanse. For at ridderen kunne kendes, bar han sit våbenmærke synligt på sin kjortel og/eller på en fane, der var hæftet til hans lanse. Når han red frem, holdt han lansen lodret eller skråt opad, først under angreb blev den fældet. Ridderne er klædt i lange kjortler (over ringbrynjen), som det også kendes fra samtidige bogillustrationer. Foran den ridder, der ses til højre for skibet, står en (fransk) lilje. Det var et kendt riddersymbol, ikke blot i Frankrig, men i store dele af Europa. Det står for renhed, høviskhed og kyskhed ("ren i tanke, ord og handling ", som det siges i spejderløftet - og spejderne bruger netop liljen som symbol), mens ridderen i sig selv er symbol på ridderlighed og tapperhed. Ikke sjældent er ridderen gengivet som Sankt Jørgen (Georg), der kæmper mod dragen (det onde) for at befri prinsessen (symbol på det gode, renhed og uskyld), der så bliver hans belønning for udvist mod og tapperhed. Sankt Jørgen ses bl.a i kirkerne i Brøns (kalkmaleri) og Broager (træfigur), dog fra en langt senere tid. Liljen kan dog også ses som et livstræ, symbol på evigt liv - eller måske sejr.

Efter liljen følger en jagtscene, hvor to myndeslanke hunde jager en hjort, der med hævet gevir springer frem mod liljen. Også jagten var et ridderprivilegium, og jagthunde hørte til enhver ridders »udstyr«, mens de var forbudte for menigmand.

Den næste figur er en stående spydmand - en fodfolkskriger, som 


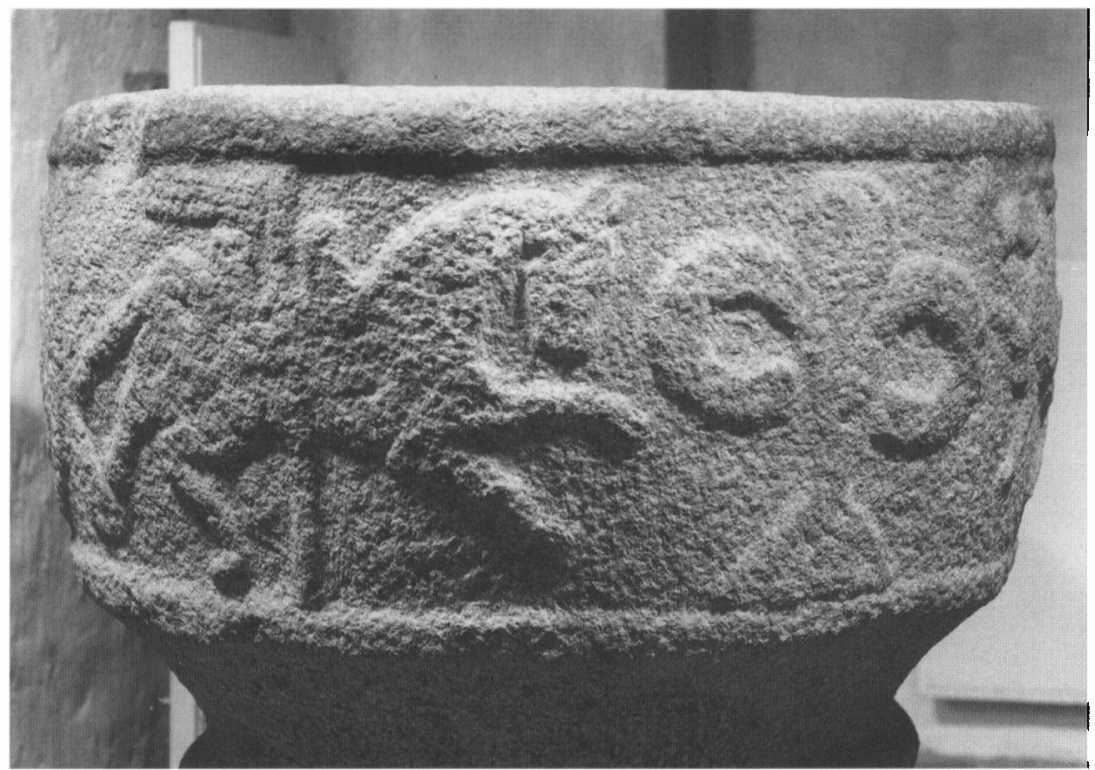

Felsted kirke, del af døbefontens kumme, ridder og lilje. Foto: Nationalmuseet, København.

han sås i den gamle danske bondeleding, hvor spydet og den danske økse (vikingeøksen) var hovedvåbnene. Øksen ses på gravsten fra vikingetid og tidlig middelalder og på enkelte kalkmalerier, da som regel som symbol på den norske helgenkonge Olav den Hellige, ligesom de kendes fra fund fra krigergrave og gamle slagmarker, ikke mindst fra Grathe Hede, hvor den jyske fodfolksleding vandt et af sine sidste store slag i 1157, da Valdemar (den Store, Knud Lavards søn) besejrede Svend Grathe (søn af Erik Emune). Manden synes at bære hjælm. Han holder et spyd $i$ den ene hånd, mens den anden hænger frit. Foran ansigtet anes et eller andet, måske et horn. Det virker blot mærkeligt, at "hornet « svæver frit i luften, mens den hånd, der skulle have holdt det, er ledig. Der er måske slet ikke noget horn, men blot en buling i stenen.

Den sidste figur, inden frisen er nået fonten rundt og igen kommer frem til skibet, viser endnu en ridder, stort set en pendant til den første, også han udstyret med lanse (?) og fane.

Der kan ikke være nogen tvivl om, at frisen fortæller et eller andet om tiden, hvor de lanse- og sværdbevæbnede "europæiske" riddere og bondeledingen med spyd og økser - og dermed den gamle nordi- 


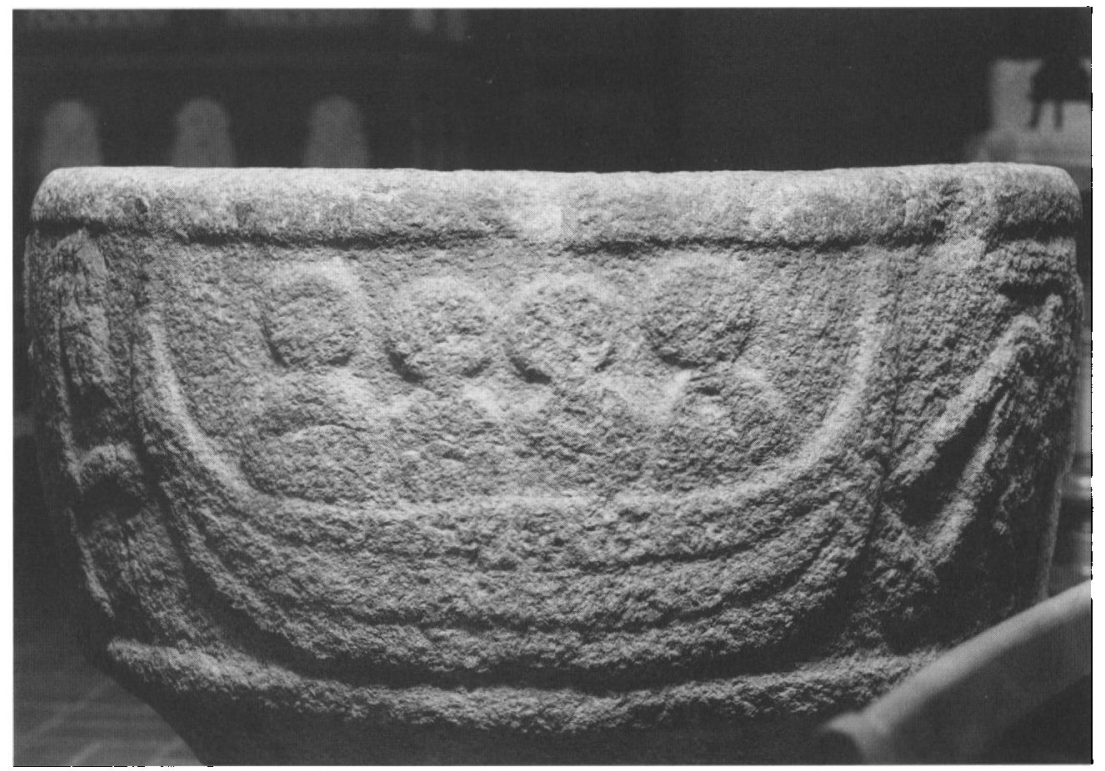

Felsted kirke, del af døbefontens kumme, båd med fire personer. Foto: Nationalmuseet, København.

ske bondekultur fra vikingetiden - kæmpede om overtaget i Danmark. Kort sagt: forste halvdel af 1100 -tallet.

\section{Knud Lavard og Magnus}

Den tid er i Danmarkshistorien personificeret $i$ to mænd, den europæisk uddannede ridder Knud Lavard, grænsejarl i Slesvig - hertug kaldte han sig efter tysk/europæisk mønster - og den hjemmetrænede prins Magnus, kaldet Magnus den Stærke eller Magnus (den) Gode. De var begge sønnesønner af Svend Estridsen og i øvrigt fætre til Karl den Danske af Flandern, der blev myrdet i Sankt Donatians kirke i Brügge den 2. marts 1127.

Knud var søn af Erik Ejegod (eller Egode), konge 1096-1103, der i høj grad plejede forbindelser sydpå og som den første danske konge foretog store statsrejser. Han besøgte paven i Rom for at få broderen Knud (den Hellige) helgenkåret, hvilket lykkedes, og 1101 fejredes en stor helgenfest i Odense, hvor hans gyldne skrin sattes på højalteret i domkirken, som derefter skiftede navn fra Sankt Albani kirke til Sankt Knuds kirke. Det er ikke den nuværende bygning, den er opført 
langt senere, i gotisk tid. Efter et par år hjemme drog Erik Ejegod som den første europæiske konge på pilgrimsfærd til det »befriede« Jerusalem for at knæle ved Kristi grav og de andre hellige steder, men den 10. juli 1103 - på dato 17 år efter mordet på broderen Knud den Hellige - døde han på Cypern, hvor han blev gravlagt $i$ et kloster. Dronning Bodil fortsatte pilgrimsfærden, men døde samme efterår på Oliebjerget, netop som Jerusalems mure var inden for synsvidde. Deres mindreårige søn Knud (opkaldt efter både sin oldemors bror Knud den Store og den helgenkronede farbror) blev sendt til Tyskland for at blive opfostret hos hertug, senere kong Lothar af Sachsen. Her modtog han som en af de første danskere den ridderuddannelse, som var gængs blandt stormandssønner ude i Europa, og som i øvrigt fætteren Karl (den Danske - eller den Gode) havde fået på borgen Wijnendale i Flandern nogle år tidligere. Ca. 1115 vendte Knud hjem og blev af farbroderen kong Niels udnævnt til grænsejarl. Selv brugte han som nævnt titlen hertug. Kort efter giftede han sig med prinsesse Ingeborg af Novgorod, og de fik tre døtre og 1131 sønnen Valdemar, der opkaldtes efter sin mors farfar, fyrst Vladimir. Knud havde stor succes i sit embede, skabte ro ved grænsen og undertvang nabostammerne og fik titel af vendernes knes (en både religiøs og verdslig titel) og konge af obodritterne.

Det skabte et modsætningsforhold til prins Magnus, søn af kong Niels, Erik Ejegods bror og efterfølger. Niels var den femte af Svend Estridsens sønner, der blev konge af Danmark: Harald Hén 1074-80, Knud den Hellige 1080-86, Oluf Hunger 1086-95, Erik Ejegod 10951103 og endelig Niels 1104-34. Han var således konge længere end de fire ældre brødre tilsammen. En sjette bror, Svend, havde været udpeget som Erik Ejegods efterfølger, men døde 1104, inden han nåede at blive hyldet på tinget.

Magnus kom ikke til udlandet for at få en ridderuddannelse, men måtte »nøjes« med den opdragelse, man kunne få på en sjællandsk stormandsgård. Han var således bærer af den gamle tradition i modsætning til det moderne riddervæsen, som Knud repræsenterede. Han var sin faders lydkonge over et rige i Mellemsverige, og som kongens søn skulle han synes selvskreven til at arve tronen, når Niels døde. Alligevel frygtede han, at Knuds succes både på den ene og den anden måde (han var jo også kongesøn og vel dermed lige så arveberettiget til riget som Magnus) skulle true hans position, og kort efter nytår 1131 myrdede han Knud i Haraldsted skov på Midtsjæl- 

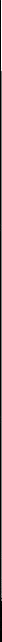

Rentegning af billedfrisen på Felsted-fonten. Den overste hunds snude går ind over hjortens hale. Tegning: H.E. Sørensen.

land, efter at de i nogle dage havde været sammen til julegilde hos
kongen i Roskilde.

land, efter at de i nogle dage havde været sammen til julegilde hos
kongen i Roskilde.

Magnus's tilnavn (den) Gode har næppe noget med hans egenskaber at gøre (i modsætning til det andet tilnavn »den Stærke«), men henviser - måske ligesom Erik Ejegod/Egodes tilnavn til en gammelnordisk titel, gode. En gode var oprindelig en hedensk præst, men i 1100-tallet, efter at kristendommen havde sejret, mistede betegnelsen
sin religiøse betydning og blev bondesamfundets eneste embeds-
mandstitel. Embede kommer i øvrigt af det gammelnordiske »om-
bud«, d.v.s. man blivet pålagt og påtager sig en tillidspost. Goden var
leder af bondeledingen i krig og af tinget i fredstid. I det hele taget
synes hans opgave i første række at have været at vogte over og vær-
ne tingets orden og ret, d.v.s. forsvare den gamle samfundsorden. 1100-tallet, efter at kristendommen havde sejret, mistede betegnelsen
sin religiøse betydning og blev bondesamfundets eneste embeds-
mandstitel. Embede kommer i øvrigt af det gammelnordiske »om-
bud«, d.v.s. man blivet pålagt og påtager sig en tillidspost. Goden var
leder af bondeledingen i krig og af tinget i fredstid. I det hele taget
synes hans opgave i første række at have været at vogte over og vær-
ne tingets orden og ret, d.v.s. forsvare den gamle samfundsorden. 1100-tallet, efter at kristendommen havde sejret, mistede betegnelsen
sin religiøse betydning og blev bondesamfundets eneste embeds-
mandstitel. Embede kommer i øvrigt af det gammelnordiske »om-
bud«, d.v.s. man blivet pålagt og påtager sig en tillidspost. Goden var
leder af bondeledingen i krig og af tinget i fredstid. I det hele taget
synes hans opgave i første række at have været at vogte over og vær-
ne tingets orden og ret, d.v.s. forsvare den gamle samfundsorden. 1100-tallet, efter at kristendommen havde sejret, mistede betegnelsen
sin religiøse betydning og blev bondesamfundets eneste embeds-
mandstitel. Embede kommer i øvrigt af det gammelnordiske »om-
bud«, d.v.s. man blivet pålagt og påtager sig en tillidspost. Goden var
leder af bondeledingen i krig og af tinget i fredstid. I det hele taget
synes hans opgave i første række at have været at vogte over og vær-
ne tingets orden og ret, d.v.s. forsvare den gamle samfundsorden. 1100-tallet, efter at kristendommen havde sejret, mistede betegnelsen
sin religiøse betydning og blev bondesamfundets eneste embeds-
mandstitel. Embede kommer i øvrigt af det gammelnordiske »om-
bud«, d.v.s. man blivet pålagt og påtager sig en tillidspost. Goden var
leder af bondeledingen i krig og af tinget i fredstid. I det hele taget
synes hans opgave i første række at have været at vogte over og vær-
ne tingets orden og ret, d.v.s. forsvare den gamle samfundsorden. 1100-tallet, efter at kristendommen havde sejret, mistede betegnelsen
sin religiøse betydning og blev bondesamfundets eneste embeds-
mandstitel. Embede kommer i øvrigt af det gammelnordiske »om-
bud«, d.v.s. man blivet pålagt og påtager sig en tillidspost. Goden var
leder af bondeledingen i krig og af tinget i fredstid. I det hele taget
synes hans opgave i første række at have været at vogte over og vær-
ne tingets orden og ret, d.v.s. forsvare den gamle samfundsorden. 1100-tallet, efter at kristendommen havde sejret, mistede betegnelsen
sin religiøse betydning og blev bondesamfundets eneste embeds-
mandstitel. Embede kommer i øvrigt af det gammelnordiske »om-
bud«, d.v.s. man blivet pålagt og påtager sig en tillidspost. Goden var
leder af bondeledingen i krig og af tinget i fredstid. I det hele taget
synes hans opgave i første række at have været at vogte over og vær-
ne tingets orden og ret, d.v.s. forsvare den gamle samfundsorden. 1100-tallet, efter at kristendommen havde sejret, mistede betegnelsen
sin religiøse betydning og blev bondesamfundets eneste embeds-
mandstitel. Embede kommer i øvrigt af det gammelnordiske »om-
bud«, d.v.s. man blivet pålagt og påtager sig en tillidspost. Goden var
leder af bondeledingen i krig og af tinget i fredstid. I det hele taget
synes hans opgave i første række at have været at vogte over og vær-
ne tingets orden og ret, d.v.s. forsvare den gamle samfundsorden.
Han var således kongens nærmeste og mest betroede mand.

Knuds tilnavn Lavard er en afledning af det oldnordiske ord "leve“ (brød) og betyder egentlig »brødgiver« (olddansk: hlaford - sammen-
lign »hlewagastiR« på guldhornsindskriften). Det er det samme ord
som det engelske »laird« eller »lord«, herre, hersker. Man siger jo
endnu: at tage/have nogen i sit brød, hvilket vil sige at ansætte no(brød) og betyder egentlig »brødgiver« (olddansk: hlaford - sammen-
lign »hlewagastiR« på guldhornsindskriften). Det er det samme ord
som det engelske »laird« eller »lord«, herre, hersker. Man siger jo
endnu: at tage/have nogen i sit brød, hvilket vil sige at ansætte no(brød) og betyder egentlig »brødgiver« (olddansk: hlaford - sammen-
lign »hlewagastiR« på guldhornsindskriften). Det er det samme ord
som det engelske »laird« eller »lord«, herre, hersker. Man siger jo
endnu: at tage/have nogen i sit brød, hvilket vil sige at ansætte no(brød) og betyder egentlig »brødgiver« (olddansk: hlaford - sammen-
lign »hlewagastiR« på guldhornsindskriften). Det er det samme ord
som det engelske »laird« eller »lord«, herre, hersker. Man siger jo
endnu: at tage/have nogen i sit brød, hvilket vil sige at ansætte nogen, at kunne befale over nogen. Alene de to prinsers tilnavne siger noget om, hvor skismaet imellem dem og deres tilhængere har ligget. Goden er samfundets tjener ("minister»), mens lorden (Lavard) er herren, den bydende.
Knud Lavards halvbror Erik (kaldet Emune, "den, der husker« -
eller »den, der huskes«) lod sig straks efter mordet i Haraldsted skov
udråbe til konge og rejste et oprør for at hævne Knud, mens deres
anden halvbror, den langt ældre Harald Kesja, der havde været sted(»minister»), mens lorden (Lavard) er herren, den bydende.
Knud Lavards halvbror Erik (kaldet Emune, "den, der husker« -
eller »den, der huskes«) lod sig straks efter mordet i Haraldsted skov
udråbe til konge og rejste et oprør for at hævne Knud, mens deres
anden halvbror, den langt ældre Harald Kesja, der havde været sted(»minister»), mens lorden (Lavard) er herren, den bydende.
Knud Lavards halvbror Erik (kaldet Emune, "den, der husker« -
eller »den, der huskes«) lod sig straks efter mordet i Haraldsted skov
udråbe til konge og rejste et oprør for at hævne Knud, mens deres
anden halvbror, den langt ældre Harald Kesja, der havde været sted(»minister»), mens lorden (Lavard) er herren, den bydende.
Knud Lavards halvbror Erik (kaldet Emune, "den, der husker« -
eller »den, der huskes«) lod sig straks efter mordet i Haraldsted skov
udråbe til konge og rejste et oprør for at hævne Knud, mens deres
anden halvbror, den langt ældre Harald Kesja, der havde været sted(»minister»), mens lorden (Lavard) er herren, den bydende.
Knud Lavards halvbror Erik (kaldet Emune, "den, der husker« -
eller »den, der huskes«) lod sig straks efter mordet i Haraldsted skov
udråbe til konge og rejste et oprør for at hævne Knud, mens deres
anden halvbror, den langt ældre Harald Kesja, der havde været sted-

over
le hos
nska-
men
nmel-
men i
helsen
beds-
»om-
tag var
vær-
orden.
leve«
umen-
e ord
ger jo
te no-
imel-
tjener
cer -
skov
deres
sted-

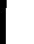

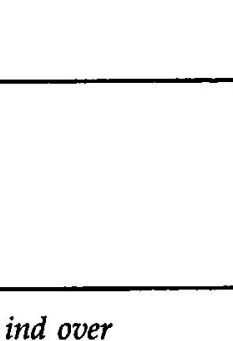


fortrædende konge for faderen Erik Ejegod under pilgrimsrejsen 110304, gik over på Magnus's parti, måske i misundelse over, at Erik var kommet ham i forkøbet. Men næppe udelukkende derfor. Også han var opdraget $\mathbf{i}$ gammelnordisk tradition, mens Erik ligesom Knud havde fået sin oplæring ved et tysk hof. Brødrene Erik Emune og Harald Kesja repræsenterede således de samme to modsatvendte kulturretninger som fætrene Knud Lavard og Magnus Gode.

\section{Slaget ved Fodevig}

I de følgende år søgte Erik flere gange uden held at slå Magnus, men først efter at have hentet hjælp i Tyskland, hvorfra han fik 300 væbnede ryttere (riddere) stillet til rådighed, lykkedes det ham pinsedag den 4. juni 1134 i slaget ved Fodevig nær Skanør på Skånes vestkyst at slå Magnus's og kong Niels's hær, hvor også broderen Harald Kesja var med. Det var den gammeldags bondehær, der her mødte sit nederlag over for det moderne rytteri. Slaget var tabt på forhånd for fodfolket, som flygtede ved første angreb, men Magnus og en flok af hans trofaste tog en "last stand " sandsynligvis på heden nær strandbredden, hvor de kæmpede som desperate og forhindrede, at den gamle konge blev fanget. Magnus selv faldt sammen med mange andre. Blandt de dræbte i slaget var flere biskopper og tres præster.

Saxo er den, der giver den fyldigste skildring af slaget: Niels "sejlede til Fodevig, hvor han stillede sin hær i slagorden tæt ved strandbredden, og således blev han stående en liden stund, til Erik rykkede frem; men da han langt borte fra så hestene hvirvle støvet op med deres hove ligesom en sky, trak han sig lidt efter lidt tilbage til sine skibe, og da han hørte gnyet af de fremrykkende ryttere, gav han sig på flugt. Da Erik indhentede hans hær, var den allerede slagen, ikke i kamp, men af skæbnen, og uden selv at lide noget mén huggede han den ned og vandt en sejr, som intet blod kostede ham, thi Gud hævnede frændemordet. Kun Magnus, som tillige med en liden flok tapre mænd undså sig ved at fly, gik løs på fjenden og søgte at drive ham tilbage, medens de andre vendte ryg, thi da han skønnede, at der kun var ringe udsigt til at slippe bort, holdt han det for en ære tappert at søge døden og at gøre sit endeligt berømmeligere ved at falde i kampen. Han foretrak døden for flugt for ikke at fordunkle sit gamle ry for tapperhed. Omsider, efter at han havde kæmpet drabelig og fældet en mængde fjender, faldt han oven på den dynge af lig, han 
havde hobet op omkring sig, tillige med bisp Peder af Roskilde, og som denne fulgte ham i døden, kom han også i samme grav «. Det er Saxo magtpåliggende at fortælle, at Magnus's nederlag og død var Guds straf over frændemorderen og hans parti. Magnus's lig førtes til hans svenske rige, hvor han begravedes i Vreta klosterkirke i Østergøtland.

Kong Niels og Harald Kesja flygtede efter nederlaget til Jylland, hvor Niels dræbtes på gaden i Slesvig tre uger senere, 25. juni 1134, mens Harald et halvt års tid efter blev hugget ned sammen med sine sønner på sin gård Skiping $\mathrm{i} J y l l a n d$ af Erik Emune, som nu var landets konge. Han blev i ovrigt selv myrdet i Ribe 1137 af storbonden Sorteplov, der i følge et lokalt sagn kom fra Spandetgård. På en eller anden måde virker de mange drab i kongeslægten med få års mellemrum næsten rituelle, uden at det dog er muligt at skaffe belæg for en sådan teori, selv om Palle Lauring har prøvet (i »Danmarks håb og horn «).

Ryd Klosters Årbog skriver: »I det slag, der stod ved Fodevig i det Herrens år 1135, faldt Magnus og sammen med ham seks bisper, fire fra Jylland, en fra Sjælland, en fra Sverige og tillige mange stormænd fra Danmark«. Men i Roskildekrøniken står: "Magnus dræbtes - og med ham jarler og biskopper: Peder af Roskilde, Thore af Ribe, Ketil af Vestervig, Henrik, som var fordreven fra Sverige. Adelbjørn af Slesvig fik et uhelbredeligt sår og overlevede knap halvanden år efter. Men en sjette, biskop Eskil (af Viborg), havde Erik to år før dette slag ladet dræbe i kirken, mens han forrettede gudstjenesten. " Henrik havde været biskop i Vesterås. Svend Aggesen nævner kun to bisper, som sammen med Magnus "sendtes til Helvede“.

Man skulle tro, at optegnelserne i klosterårbogen var nedskrevet omtrent samtidig med begivenhederne - eller i hvert fald kort efter, men det forkert angivne årstal viser, at det må være sket $i$ hvert fald nogle år senere. Derved er opstået den misforståelse, at alle seks bisper blev dræbt i slaget, mens Roskildekrøniken, der må anses for den mest samtidige kilde, nøjagtigt redegør for de enkelte bispers død. Nemlig, at fire blev dræbt i kampen, en var myrdet to år tidligere, og en døde af sine sår halvandet år senere.

Saxo er mere loren ved den kendsgerning, at bisperne kæmpede på Magnus's side, hvilket ikke helt svarer til det billede, han gerne vil give af danskernes holdning over for Magnus som Knud Lavards morder. Han skriver: »I ingen anden krig er der blevet udgydt mere bispeblod, 


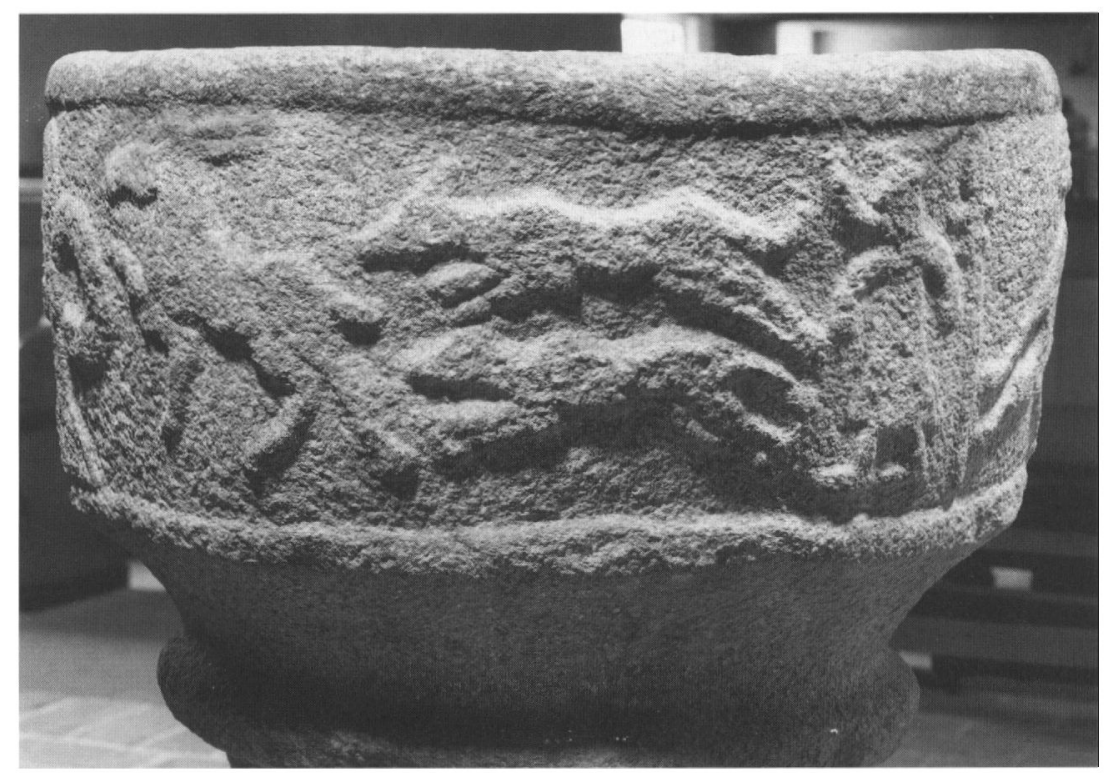

Felsted kirke, del af døbefontens kumme. Til høire jæger med spyd og jagthorn, som med sine to hunde ( $i$ midten) jager en hind (yderst til venstre). Foto: Nationalmuseet, Kobenhavn.

thi Peder af Roskilde og den svenske biskop Henrik og alle de jyske bisper på én nær skal være omkomne i det slag«. Bortset fra det tidligere citerede om bisp Peder, der faldt sammen med Magnus, siger Saxo ikke noget om, på hvis side bisperne kæmpede! Og med udtrykket »skal være omkommet« dækker han, at to jyske bisper ikke blev dræbt, og for i hvert fald den enes vedkommende - næppe deltog i slaget. Det er dog sandsynligt, at den ellers særdeles velunderrettede Saxo, der havde adgang til alle samtidige kilder, har vidst besked, men at virkeligheden ikke svarede til det billede, han ønskede at give.

Alle senere kilder, ikke mindst Saxo, der skrev o. 1200, er på Knuds og Erik Emunes side i striden mellem kongsemnerne. For ham er Magnus en simpel forbryder, der snigmyrder sin fætter og ven, og Knud Lavard gøres til en lysende helt og helgen, der da også 1169 blev kanoniseret af paven og året efter skrinsattes i Ringsted klosterkirke, hvor han hidtil havde været gravlagt under gulvet. Klosteret $\mathbf{i}$ Ringsted var et benediktinerkloster, stiftet af Svend Estridsen o. 1070. Kirken fik dog ikke Knuds navn, men hed fortsat Sankt Bendts (Benedikts) kirke, måske for ikke at skabe forveksling med Knudskirken i 
Odense. Legender fortalte om undere på graven. I Haraldsted ses stadig fundamentet til det kapel, der rejstes på mordstedet, og hvor en kilde sprang frem af den jord, der havde drukket martyrens blod.

Men det er ikke sikkert, at alle i samtiden var enig i den opfattelse. I Roskildekrøniken, der som nævnt er skrevet kort efter begivenhederne, står følgende mindeord om Magnus, der er noget af det mest følelsesladede, vi har fra dansk middelalder: "Erik kom over dem med sin hær og påførte hele Danmark et ubeskriveligt og ubodeligt tab. Vé hint grufulde år, hin bitre dag, dødens dag, mørkets dag, fuld af jammer, tung af gråd! Vé hin dag, da Magnus dræbtes, Danmarks blomst knækkes! Den skønneste blandt de unge, kæk og kraftig, en glad giver, både klog og en ynder af fasthed: Magnus dræbes«. Om mordet på kong Niels hedder det: "troløst blev han dræbt«. Senere kaldes begivenheden »den skændige udåd «. Biskop Adelbjørn kaldes "troløs«, fordi han - biskoppen i Knud Lavards egen by Slesvig kæmpede på Magnus' side. Og sejrherren Erik Emune får denne karakteristik: "Erik førte sig overalt frem, som om han var kejser, ryddede alle hindringer af vejen, tålte ingen ligemand, endsige overmand; overmodig, opblæst, stor i ondskab, skrækkelig i al sin færd fór han frem som et lyn. Hvis der var nogen, der så ud til at eje noget, røvede han det fra de grædende mennesker og delte det ud blandt de rige og skadefro«. Ingen kan være i tvivl om forfatterens mening. Han var sandsynligvis en munk ved domkapitlet. Roskilde havde været Magnus's by, og munkens herre, biskop Peder af Roskilde, var faldet ved hans side. Sådan var opfattelsen i Magnus's parti, når man kunne udtale sig uden censur.

Den Danmarkshistorie, som de fleste af os kender, er præget af Saxo. Som den danske middelalders storste forfatter og stilist har han gennem sit vældige værk »Danernes bedrifter« (Gesta danorum) i høj grad påvirket alle de senere århundreders opfattelse af Valdemarstiden. Men Saxo var ikke alene sejrherrernes historieskriver. Han var også Danmarkshistoriens største propagandist og PR-mand. Som ansat hos Valdemar den Stores førstemand, ærkebiskop Absalon, sørgede han for, at det blev Valdemars og Absalons opfattelse af begivenhederne og de personer, der formede dem, der blev Danmarkshistorien.

Blandt andet derfor fik Magnus ry som en stimand og morder, mens Knud Lavard, Valdemar den Stores far, fremstilles som en helgen og et ridderligt forbillede for ungdommen. Og sådan har det været helt op i vore dage. 
Der kan dog ikke herske nogen tvivl om, at den danske kirke - og vel nok størsteparten af det danske folk, incl. mange stormænd - var på Niels's og Magnus's side. Når tres præster faldt i slaget, kan man gisne om, hvor mange der deltog. Det må have været betydeligt flere, sandsynlig langt over hundrede. Fire bisper faldt og én blev alvorligt såret. Der var den gang otte bispedømmer i Danmark, nemlig foruden de nævnte Århus og Lund, hvoraf det sidste var ærkebispesæde. Her sad Asser, der var kommet til embedet omtrent samtidig med, at Niels var blevet konge, i 1103. Han var i hænderne på Erik Emune, som havde opslået sit hovedkvarter i Lund og vel truet ham over på sin side. I øvrigt ville ærkebispen næppe have været meget værd på slagmarken, da han i 1134 var over 80 år. Århusbispen Ulfkels skæbne er ukendt. Ganske vist siger Palle Lauring $i$ "Valdemarerne", at han faldt ved Fodevig, men han nævner ham ikke i "Danmark i Skåne". Saxo antyder det samme, når han skriver, at »alle jyske bisper på nær én « skal være faldet, men det er mærkeligt, at Roskildekrøniken, der ellers er meget nøjagtig på dette punkt, ikke nævner ham. Men Saxo er som antydet heller ikke helt pålidelig $i$ denne sag. Biskop Eskil af Viborg var som nævnt blevet dræbt et par år tidligere, og hans efterfølger, ærkebisp Assers bror Svend, deltog ikke i slaget og var i øvrigt på Assers (og dermed Erik Emunes) side som måske den eneste af de menige bisper.

De fleste historikere, der har skrevet om disse begivenheder, noterer kort, at der faldt fem (eller seks) bisper, men de overser, at Adelbjørn af Slesvig først døde af sine sår små atten måneder senere. Det gør en forskel. I selve slaget faldt fire bisper, og man må formode, at den maltrakterede Adelbjørn er blevet ført til sin bispegård i Slesvig eller, hvis han har været for svag til det, så i det mindste til den nærmeste bispegård, i Lund eller Roskilde, eller til et kloster -, hvor han udåndede henimod jul 1135.

\section{Fodevig på fonten - et tolkningsforsøg}

I skibet på døbefonten i Felsted sidder fire personer. Et skib er et ofte benyttet symbol på rejsen til det hinsides. Kendt er det således, at færgemanden Karon i den gamle græske forestillingsverden fragtede de døde sjæle over floden Styx til indgangen til underverdenen, Hades, de dødes rige, hvor der »råder gråd og tænders gnidsel«. Det er måske derfor næppe tilfældigt, at der på fontefoden under skibet er udhugget billedet af en hund - dødens symbol. 
Skibssymbolikken er også kendt fra nordisk oldtid, bl.a. på helleristningerne, hvor solen ofte afbildes sammen med et skib, som måske skulle fragte den livgivende klode gennem dødens nat fra aften til morgen. Det er derfor naturligt at tolke billedet således, at det viser fire afdøde. Det er fristende at se dem som de fire faldne bisper fra Fodevig, og denne tolkning styrkes af fontefodens fire hoveder, der alle synes at have tonsur - eller at have båret (bispe)huer.

Ser man fonten $\mathrm{i}$ dette lys, er der flere ting, der synes at passe sammen. Det fremtrædende liljesymbol (livstræet?) kan tolkes som et demonstrativt - nærmest provokerende - sejrstegn, og de to lanseeller fanebærende riddere som triumferende sejrherrer. I hvert fald havde Knudsgildet i Slesvig (Knud Lavards gilde) en fuldt rustet ridder $\mathbf{i}$ sit segl, der minder meget om ridderne på Felstedfonten. Mon ikke Knudsgildets segl spejler Knud Lavards segl, som vistnok ikke er bevaret? Også hans bror, Erik Emune, brugte ridderbilledet som sit mærke. Det ses bl.a. af mønter fra hans tid. I øvrigt var ridderbilledet almindeligt på segl for medlemmer af den øverste klasse dengang. Både Knud den Hellige og hans søn Karl den Danske havde såkaldte equestersegl - af det latinske equus, hest.

Spydmanden symboliserer da den slagne bondehær, eller måske er figuren et cadeau til ridderhærens fodfolk. Hjorten kunne vise den flygtende kong Niels, der skyndsomt fjerner sig fra slagmarken, men jages til døde af riddernes jagthunde. En anden mulighed er, at hjorten henviser til Skjalm Hvides æt, der var nært forbundet med Knud Lavard og hans slægt i venskab. Mange medlemmer af den magtfulde Hvideslægt førte hjortegeviret som våbenmærke. Ærkebiskop Absalons våbenskjold på hans gravsten fra o. 1520 og på senere gengivelser viser en springende hjort, ikke ulig hjorten på Felstedfonten.

Således fortolket bliver døbefonten til et monument for slaget ved Fodevig, rejst ret kort efter begivenhederne, sandsynligvis 1134 eller senest året efter, i hvert fald udført, inden biskop Adelbjørn var død, hvilket sandsynligvis skete sidst på året 1135 .

Hvem der lod fonten udfærdige og stille op i sin kirke, kan vi naturligvis ikke sige noget om i dag, men umiddelbart taler sandsynligheden for, at det må have været en stormand på Erik Emunes og dermed ridderpartiets side. Meget $i$ fontens udsmykning peger hen på, at der er tale om en person med en ret nær tilknytning til Knud Lavard-fløjen i datidens politiske billede. Det lader sig desværre ikke gøre at give ham navn, da vi ikke kender de lokale stormænd i Fel- 
sted sogn så langt tilbage. Men det er nok mest sandsynligt, at han har siddet på en af sognets storgårde.

Det er samtidig fristende at sætte fonten i forbindelse med indvielsen af den stenkirke, som sandsynligvis omkring dette tidspunkt kan have afløst den oprindelige stavkirke, der vel da var omkring hundrede år gammel og dermed udtjent.

Selv om meget $i$ tolkningen af Felstedfontens billedfrise naturnødvendigt må være uklart, forekommer det mig sandsynligt, at den kan have en nær forbindelse med begivenhederne i 1130'erne, ikke mindst Fodevigslaget. Er det rigtigt, står vi over for det ældste krigsmonument herhjemme, der kan henføres til en kendt og daterbar begivenhed, og Felstedfonten bliver derved et meget vigtigt monument fra en af de mest turbulente perioder i Danmarkshistorien.

\section{LITTERATUR}

Aggesen, Svend: Historiske skrifter. 191617.

Birkebæk, Frank m.fl. (red): Absalon, fædrelandets fader. 1996.

Danmarks kirker. Aabenraa amt. 1959.

Fabricius, A.: Illustreret Danmarkshistorie for folket I. 1914.

Fabricius, L.P.: Danmarks kirkehistorie, I. 1934.

Fenger, Ole: "Kirker rejses alle vegne«. 1050-1250. Gyldendal og Politikens Danmarkshistorie. 1989.

Galbert of Bruges: The Murder of Charles the Good Count of Flanders. Translated and edited by James Bruce Ross. 1959/ 1967.

Gregersen, H. V.: Slesvig og Holsten indtil 1830. 1981.

Horskjær, Erik (red): De danske kirker, bind 17. 1970.

Knytlingesaga. 1977.

Koch, Hal: Det danske folk 1042-1241. Schultz's Danmarkshistorie. u.å.

-: Kongemagt og kirke 1060-1241. Politikens Danmarkshistorie. 1963.

la Cour, Vilh.: Tiden indtil 1241. Sonderjyllands historie I. 1931.

Lauring, Palle: Danmark i Skåne. 1952/ 1961.

-: Danmarks håb og horn. 1954.

-: Valdemarerne. 1959.

Mackeprang, M.: Danmarks middelalderlige døbefonte. 1941.
Melckers, Erna u. Hans: Das grosse Buch der Heiligen. 1978.

Nancke-Krogh, Søren: Stenbilleder i danske kirker. 1995.

Nielsen, Kay: Danmarks konger og dronninger. 1980.

Nielsen, Niels Skyum: Kvinde og slave. 1971.

Olrik, Hans (udg.): Danske helgeners levned. 1968.

Olsen, Olaf og Ole Crumlin-Pedersen: Fem vikingeskibe fra Roskilde Fjord. 1969.

Præsten Helmolds Slavekrønike. 1881.

Rieck, Flemming og Ole Crumlin-Pedersen: Både fra Danmarks oldtid. 1988.

Roskildekrøniken. 1979.

Ryd klosters årbog. 1989.

Salmonsens leksikon.

Saxo: Danmarks krønike. Oversat af Fr. Winkel Horn. 1898/1975.

Saxtorph, Niels M.: Jeg ser på kalkmalerier. 1979.

Steenstrup, Johannes: Det danske folk 1042-1241. Det danske folks historie II. 1927.

Sirensen, H. E.: Sundeved. 1983.

-: Slotte, herregårde og voldsteder i Sonderjylland I. 1994.

Trap Danmark. Aabenraa amt. 1967.

Volborth, Carl Alexander von: Alverdens heraldik i farver. 1972.

Wegener, C.F.: Om Carl Danske, Greve af Flandern. 1839. 